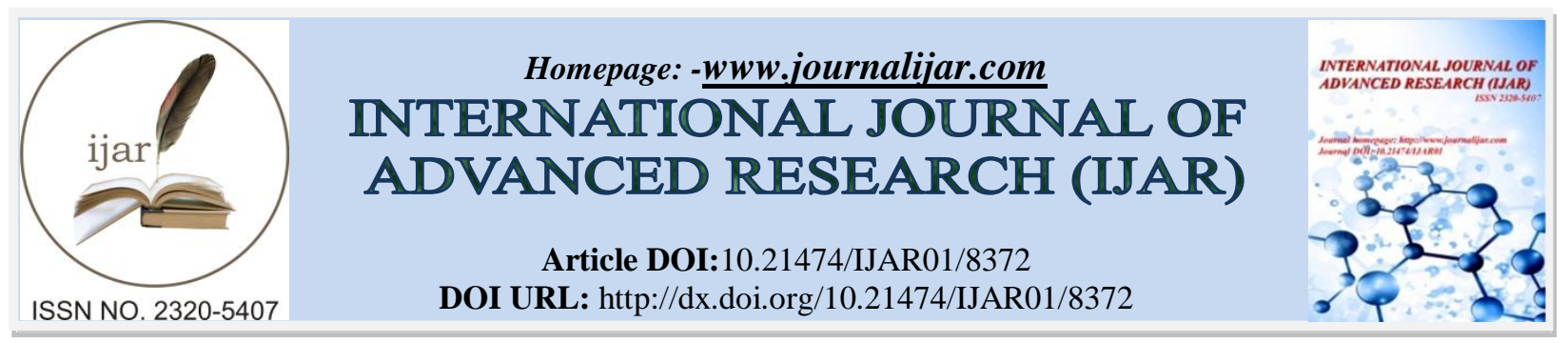

RESEARCH ARTICLE

\title{
EMPLOYABILITY AND PRODUCTIVITY OF BACHELOR OF ELEMENTARY EDUCATION GRADUATES IN TOMAS CLAUDIO COLLEGES.
}

\author{
C. Penaranda. \\ College of Education, University of Rizal System/Tomas Claudio Colleges Morong, Rizal.
}

\section{Manuscript Info}

\section{Abstract}

Manuscript History

Received: 10 November 2018

Final Accepted: 12 December 2018

Published: January 2019

Copy Right, IJAR, 2017,. All rights reserved.

\section{Introduction:-}

\section{The Problem And Its Background:-}

Education plays a significant role in developing the full potential of an individual most especially in developing his total personality and economic well-being. Thus, the education and development of an individual should always be given priority.

The economy of the country faces a serious social problem which is in relation to employment crisis. Many instances showed that the country is slowly moving towards progress in terms of education, nourishment and production. The government's primary concern is to supply more jobs to its constituents in order to survive. Thus, there is a mandatory law in the Philippine Constitution for every legal citizen that addresses quality employment for all.

As stated in Article XIV, Section 3 of the 1987 Philippine Constitution that:-

The above mentioned provision focused on creating enough job employment opportunities to those individuals for certain measures that shall provide appropriate employment for all persons who are capable to work.

On the other hand, the Secretary of the Department of Labor and Employment (DOLE) noted that over a million Filipinos found jobs in April 2014. Citing the April 2014 Labor Force Survey (LFS), the country's total employed persons increased to 30.4 million.

The LFS showed that the highest in services, which provided 900,000 jobs, was in 2014. This was followed by industry and Agriculture, 270,000 jobs.Wages and salaries also grew, 14-16.072 million in 2003-2004.

The labor scenario of the Philippines show paradox nature since DOLE noted that many graduates could not find good employment. Thus, problem on shortage of qualified manpower increases despite supply over graduates. Apparently, there may be mismatch on the acquired learning with that of the labor market.

Education is one of the agents necessary for maximum realization of the country's national development. The success of the education as an instrument for progress depends on the quality of its manpower.

That is why the government must provide quality education for all which is stated in Article XIV, Section 4 of the 1987 PhilippineConstitution:

Corresponding Author:-C. Penaranda.

Address:-College of Education. University of Rizal System/ Tomas Claudio Colleges, Morong, Rizal. 
'The State shall protect and promote the right of all citizens to quality education at all levels and shall take appropriate steps to make such education accessible to all.',

The mentioned provision, therefore, affirms that the government is doing its best to provide quality education for every citizen especially in areas where there are little opportunities for a better education. They have to find ways on how they will meet the demands of stable employment through education.

Some researchers found out that many course contents offered in educational institutions have not contributed in the increase of the employment. Instead, it contributes to the growing number of discontented and frustrated young graduates. If the error of the school curriculum remains unchecked, it will continuously contribute to the growing graduates who become surplus of the country because of their inability to be employed.

It has been observed that unemployment of college graduates in the Philippines was a voluntary nature. Graduates were still in the hunting stage, evaluating various job and career options, and therefore the problem is not serious and maybe considered more of transition problem from the world of academe to the world of work. These graduates are in a sense not in state of unemployment but are actively in search of a job. The gravity of the problem of unemployed graduates in search of a job varies by type of institution and curricular program. It is also very evident that some graduated were underemployed which means that they engage themselves in an occupation which is not in line with their area of specialization which is elementary education.

It is in this light that a study to assure the effectiveness of a teacher education program in Tomas Claudio Colleges was conducted. This focused on the employability and productivity of Bachelor of Elementary Education graduates from School Years 2012-2013,2013-2014 and 2014-2015.

\section{Setting of the Study:-}

The study was undertaken at Tomas Claudio Colleges, formerly Tomas Memorial College and the surrounding areas. The graduates of the institution are from the different towns in Eastern Rizal like Morong, Baras, Tanay, Pililla, Jala-jala, Teresa, Antipolo, Cardona, Binangonan, Taytay with some residents of the neighboring province of Laguna. Figure 1 shows the location of the school in the town of Morong, Rizal.

Under the College of Education and Liberal Arts, Bachelor of Elementary Education is offered with major in General Education. The study was conducted in Tomas Claudio Colleges, Morong, Rizal during the School Years 2012-2013,2013-2014, and 2015-2016. Tomas Claudio Colleges has been bestowing responsive quality education and community involvement for more than sixty years. The collage envisions being the best institution of learning empowered to educate youth to become responsible leaders of community, to instill in them the Claudian spirit and to maintain as benchmark in the field of technology, and its mission to provide basic instructions that will prepare them succeed in today's rapidly changing world; develop citizens who are productive, god-loving, honest, selfreliant, and committed to conserve the country's natural resources. The College vision it to be the beacon light of excellence, competence and sustainable development in the citadel of education. While it's mission is to develop globally competitive educators equipped with academic and technical skills and values necessary in a rapidly changing world.

TCC has gone a long way, from a small community college. it has now metamorphosed into a reliable institution of learning committed to the pursuit for academic excellence and capable of rising to the challenge of the new century. Figure 1 shows the Vicinity Map of Tomas Claudio Colleges.

\section{Theoretical Framework:-}

The study was anchored on the Theory of Humanistic Education by Patterson (2008). The focus of this approach leads to preparing the student for responsible citizenship rather than the students' development as an individual or as a person.

This theory went beyond the early extension of education not just the development of one's intellect but to the extent of preparation for making a living through the development of vocational - technical curricula concerned with the preparation for living. This theory is related to the present study since it aims to assess whether the graduates of BEEd were already engage in the teaching field and living out of what they have learned in their educational program. 


\section{Conceptual Framework:-}

The conceptual framework of the study shows the interplay of the employability and productivity of the graduates of Bachelor of Elementary Education major in General Education in the School Years 2012-2013, 2013-2014 and 2015-2016.

The first frame includes the input consisting of the following the profile of the respondents such as sex, year graduated and eligibility, the status of employment such as nature of employment, nature of work and nature of Appointment; the level of productivity which consists of professional activity, and community involvement.

The second frame refers to the process which includes the modification of questionnaire-checklist, its administration and retrieval, and the tabulation, analysis and interpretation of data.The third frame refers to the output which is action plan to enhance the status of employability and productivity of the Bachelor of Elementary Education graduates in Tomas Claudio Colleges. The arrows indicates the continuous process with feedback indicating that if the result is not successful after getting the feedback, another process will be executed until it attains the desired result.

Figure 2 shows the conceptual model showing the employability and productivity of the graduates of Bachelor of Elementary Education.

\section{INPUT}

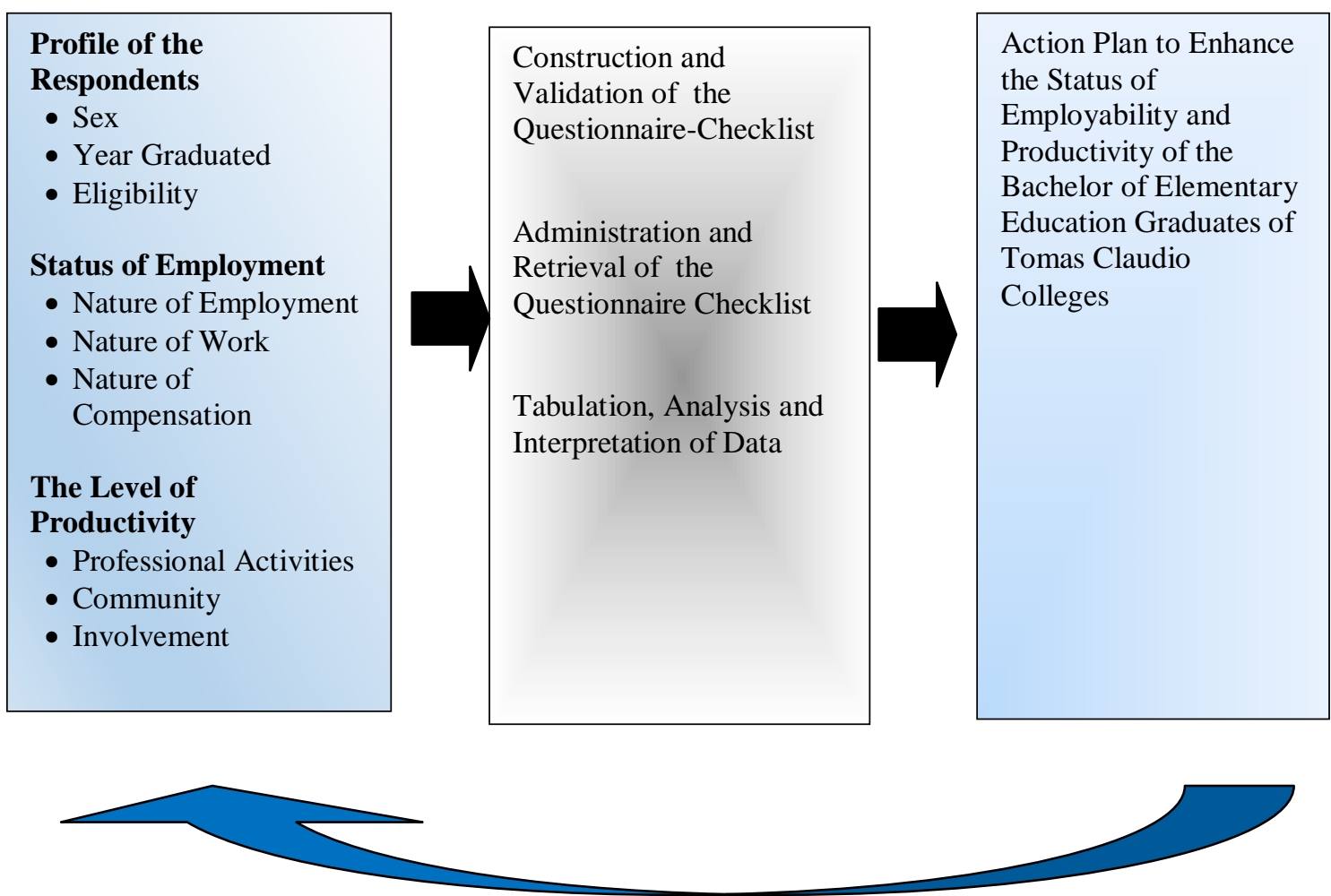

Figure 2:-Conceptual Model Showing the Employability and Productivity of Bachelor of Elementary Education

Statement of the Problem:-

\section{Graduates}

This study aimed to determine the employability and productivity of Bachelor of Elementary Education graduates during the School Year 2012-2013, 2013-2014, and 2014-2015.

Specifically, it sought to answer the following questions:-

1. What is the profile of the respondents in terms of:

1.1 sex:

1.2 year graduated;and 
1.3 eligibility?

2. What is the status of employability of the respondents with respect to:

2.1nature of employment;

2.2 nature of work;and

2.3 nature of Appointment?

3. Is there a significant association between the employability of the respondentsin terms of the above mentioned categories in terms of their profile?

4. What is the level of productivity of the respondents with respect to:

4.1 professional activities;and

4.2 community involvement?

5. Is there a significant differenceon the level of productivity of the respondents with respect to the above cited aspects in terms of their profile?

6. Based on the findings of the study, what action plan may be proposed to enhance the status of employability and productivity of the Bachelor of Elementary Education graduates of Tomas Claudio Colleges?

\section{Hypotheses of the Study:-}

This study tested the null hypotheses stating that:

1. There is no significant association on the status of employability of the respondents with respect to nature of employment, nature of work and nature of Appointment in terms of sex, year graduated and eligibility.

2. There is no significant difference between the level of productivity of the respondents with respect to professional activities and community involvement in terms of sex, year graduated and eligibility.

\section{Significance of the Study:-}

The study on the employability and productivity status of Bachelor of Secondary Education graduates will be beneficial to the following:

\section{The Institution:-}

The study will serve as guide for the administration and management of Tomas Claudio Colleges in providing sufficient information for the career-follow up program of the BEEd graduates. It is an opportunity for the school to be able to measure the effectiveness of the BEEd program, in relation to its mission and vision.

\section{Academic Coordinator of the College of Education:}

The study will help the dean to develop new teaching methods and techniques for the faculty by sending them to conferences, workshops, training and linkages with focus on teaching strategies to keep abreast with the changing educational milieu.

\section{Education Department:-}

The results of this study will help theEducation and Liberal Arts departmentto improve the curriculum and instructional approaches, in providing quality education and produce effective and efficient BEEd graduates. Likewise, it will determine if the lessons learned inside the classroom are used in the workplace to become an effective and dynamic teacher.

\section{Faculty:-}

In this study, faculty members will become aware of their products (graduates) including their employment status that could serve as an inspiration to become more motivated in molding future professional teachers. The study will also serve as evidence that the faculty have produced productive and effective individuals with instilled Claudian values such as love of God and self-discipline. It will inspire the instructors as they see their products molded in the right th with good career ahead of them.

\section{Students:-}

With the findings of this study, students will see the prospective careers waiting for them through the successful alumni doing good in their field of teaching. It will arouse them to strive hard in their studies to become successful individuals in the future, like the alumni ahead of them. 


\section{Parents:-}

Parents will have a good preview of the possible outcome of their children's education, that with proper guidance and training from the college, they will be able to become productive and responsible members of their community.

\section{Community:-}

The data gathered from the graduates of BEEd could serve as essential input to the community development profile, as every alumnus us an additional source of man power, prestige and pride to the community, role model and responsible tax payer contributing to the growth of the economy.

\section{Future Researchers:-}

This study will guide the future researcher to conduct studies or investigation concerning the employment status and teaching skill of the BEEd graduates.

\section{Scope and Limitation of the Study:-}

The aimed to determine the employability and productivity of Bachelor of Elementary Education graduates during the School Year 2012-2013, 2013-2014, and 2014-2015. The respondents of the study were the total population of the graduates during the School Years 2012-2013, 2013-2014 and 2014-2015. The respondents were described in terms of sex, year graduated and eligibility.

The employability of the respondent was determined in terms of nature of employment, nature of work and nature of appointment. The level of productivity was determined which consists of professional activities and community involvement. Data were obtained through a checklist consisting of three parts. Descriptive survey research was utilized in the study.

\section{Definition of Terms:-}

The following terms were conceptually and/or operationally defined for common point of understanding and for the guidance of the readers.

\section{Eligibility:-}

It pertains to the passing in the Licensure Examination for Teachers of an individual who finished bachelor's degree in education.

\section{Employability:-}

It pertains to the graduates working status whether they teach, or are entrepreneur or simply unemployed.

\section{Nature of Appointment:-}

This refers as to whether the employed respondent is permanent, casual, regular, contractual or provisionary.

\section{Nature of Employment:-}

This pertains as to whether the respondents is employed, unemployed or self-employed.

\section{Nature of Work:-}

This pertains to the type of work the respondents are engaged applying what they have learned in their course degree.

\section{Productivity:-}

It pertains to the level of performance of the graduates depending on their position as an employer, teacher and entrepreneurship and also depending on their income on monthly basis.

\section{Professional Activities:-}

They refer to the involvement of the teacher as a resource speaker, class adviser and membership in professional organization.

Sex:-

This term pertains as to whether individual is male or female. 


\section{Year Graduated:-}

This term pertains to the school year when the graduate respondents finished their BEEd course that is either School Year 2012-2013, 2013-2014 and2014-2015.

\section{Review Of Related Literature And Studies:-}

This chapter presents the literature and studies both foreign and local which is related or has some bearing with the present investigation.

\section{Foreign Literature;}

As stipulated by Akinwumi (2002), that the impact of principal supervisory techniques on teacher productivity in Oyo State Secondary Schools. An ex-post -facto research design was adopted for the study. The stratified random sampling techniques were used to select 85 schools from among 318 public secondary schools and 15 private secondary schools among 47 private secondary schools in Oyo State. 1, 600 respondents consisting 100 principals 500 teachers and 100 students were used in the study. While data were collected through the use of questionnaire tagged "Teacher Productivity Questionnaire" (TPQ) and participant observation. The study discovered that, supervision has no significant impact on productivity of both high and low income earning teachers. It was also revealed that supervision has greater impact on teacher productivity in public schools than in private schools. Based on the findings it was recommended that attention should be paid to supervision mechanism details and be effectively implemented.

Moreover, according to Marsh and Hattie (2002) that there is a strong rationale reinforcing the claims that research should contribute to teaching. Research forms the basis of the content of teaching. Teachers who are active researchers are more likely to be on the cutting edge of their discipline and aware of international perspectives in their field. Because textbooks may not be current in many rapidly developing areas, lectures may be the first point of contact with the latest developments. Teachers who are involved in research are more likely to be at the forefront of their discipline. Results from one's research can be used to clarify, update, and amend the teaching of a topic. Research enhances teaching through the introduction of new topics and methodologies. Teachers discussing their own research provide a sense of excitement about the results and how they fit into a larger picture. Active researchers are more effective at instilling an actively critical approach to understanding complex research findings rather a passive acceptance of facts. Students appreciate teachers who present research that the teachers have actually conducted. This provides an authenticity to the presented material that differs from presentations by teachers who are only discussing the work of others in which they have no active involvement.

Similarly, teaching should contribute to research. The process of teaching the subject matter of a discipline forces academics to clarify the big picture into which their specific research specialization fits. Preparation of teaching materials can elucidate gaps in the academic's knowledge base. Sharing the results of one's research with students in a teaching context helps researchers clarify their research. Students' suggestions, comments, questions, and criticisms can elucidate new research directions. Sharing the results of one's research efforts with an appreciative audience provides reinforcement for having done the research and pursuing further research.

As stated by Dickinson (2011), that elementary teacher preparation programs may exclude disabled students because of faulty assumptions about their employment opportunities. This study asked superintendents, certification officers, elementary teacher educators and teacher placement directors to judge the employability of variously disabled elementary teachers. There were marked differences in the apparent employability of disabled teachers, with social deviants judged less acceptable than persons with severe sensory or motor impairments. The existence of small numbers of respondents who judged virtually all the examples to be employable suggests that disabled applicants could find employment as elementary teachers.

Shulls and Trivitt (2015) examined the relationship between observable teacher characteristics and productivity as measured by an increase in student achievement on a standardized test using a value-added approach. This analysis focused on teachers of algebra, geometry, and 11th grade English Language Arts in Arkansas. The authors generated a value-added score at the school-course level and attributed that score to each teacher of that course in the school. The authors then regressed observable teacher characteristics on the value-added measure. The authors found no evidence that teacher certification route affects student tests scores, but found that higher ability math teachers do lead to higher scores. 


\section{Local Literature:-}

According to an article in the collegeview.com, the importance of the college education is also accentuated because of the opportunity to gain valuable resources during the student's tenure. The more connections the students collected during their college years, the more options they will have when they begin their job search. Once they have ended their job search and have started their career, however, the importance of a college education has not been exhausted. Having a college degree often provides for greater promotion opportunity.

It is yet true that people who engage college degree will have greater employment opportunity than those who did not finished a degree for the reason that a college graduate invested time to learn more after graduated in high school and undergoes rigid training in their colleges or universities where they graduated.

De Guzman and De Jesus (2008) stated that graduates are exhorted to develop personal skills, qualities, and experiences that enable them to compete in the labor market (Moreau \& Leathwood, 2006; McQuid \& Lindsay, 2005). This graduate tracer study (GTS) creates an empirical portrait that describes the employment aspects of the graduates of a comprehensive university in the Philippines during the years 2001-2004 to identify policy imperatives for greater relevance of higher education curricula to industry needs and expectations. A sample of 540 randomly selected graduates representing various disciplines participated in this study. Data were gathered through a survey instrument developed by a pool of experts identified by the Commission on Higher Education (CHED) in the Philippines. Data were treated in-depth through descriptive and inferential statistics. Graduates of the institution under study pursue advanced studies and other work-related training. The impressive employability profile of comprehensive university graduates to middle level management positions particularly those representing the social behavioral sciences, natural sciences, medical fields, engineering and technology and mass communication is brought about not by the academic honors of the graduates but through capabilities such as knowledge, skills and attitudes used in work places. There is a need to develop a more functional framework for employability where the diversity of fields of study offered in universities are linked to the diversity of employment is also discussed in this paper.

According to Zulueta (2004), the program as any organized and systematic learning conducted largely outside the formal educational subsystem that may or may not provide certification. Definition asides, the characteristics of nonformal education make it quite different from the formal subsystem in-a number of ways. First, non-formal education addresses the needs of those who were not able to participate in the formal subsystem. In this regard. The clientele are quite different. A substantial number dropped out of the formal subsystem, the reason for this being numerous though mostly centred on poverty. The organization, specific activities and delivery methods associated with non-formal education are designed to meet the express needs of district clientele. At the present, non-formal education in the Philippines has four thrusts, such as: family planning; vocational skills; functional literacy; livelihood skills.

Moreover, according to Ballon (2007) graduates are faced with the challenge of acquiring employment right after graduation. It is paramount that they should have gained the best knowledge and skills in their field of specialization before plunging into any workplace of their choice. A school plays a very important role in providing higher education courses to students who will eventually become graduates with full competence in their fields of study.

A graduate who leaves the sanctuary of the academe desire to find the best employment out there in the job market. However, a job seeker's desire for the best job is hampered by lack of basic skills relevant to the job, lack of experience, poor communication and social skills and among others.

Graduate related factors, competencies learned in college, mode of job search and career-choice related factors can be considered as predictors of employability of graduates. Age, civil status, region of origin and educational attainment are graduate related factors that predict graduate employability. Competencies in human relations, communication and Information Technology serve as advantages to young graduates in looking for employment. Graduates who are recommended by someone and with strong passion for the profession immediately find employment.These predictors of employability once perfectly honed and acquired are answers to the issues that bedevil young graduates and job seekers. 


\section{Foreign Studies:-}

According to the study of Yahya Buntat, et al. (2012), the employability skills that are integrated into the agricultural vocational education programs in Malaysia and their importance to employers in industry. The sample consisted of one hundred and thirty(130) teaching staff from vocational agricultural institutions and one hundred and fifty two (152) agricultural employers representing the industry. The study found that the five mean elements of employability skills which were always integrated by the teaching staff of agricultural vocational training institutions during the teaching process were: "cooperating with others", "working in a team", "possessing honesty", "following instructions given", and "interacting with others". Five mean important elements of employability skills needed by employers in the industry were: "possessing, cooperating with others", "using technology instrument and information systems effectively", "making decisions", and "managing times". Three main constraints that the teaching staff of agricultural vocational training institutions have to face in order to integrate the elements of the employability skills are; "did not clearly understand the term of employability skills", "Curriculum designed not emphasized on employability skills", and "No evaluation of employability".

The related study is parallel to the present study since both studies used the employability as their variables in the said studies.

According to the study conducted by Leggott and Stapleford (2016), which was inspired by the Dearing Report, aimed to explore the nature of student perception of their skills development. Taking place over five years and involving 35 undergraduate students, the study found that students had a low awareness of the skills that they were intended to develop and many of them were unaware of the skills requirements of employers. As a result of these findings, Personal Development Plans were used to bridge this gap and it is hoped that the experience gained form this study can be transferred to other contexts.

The researchers and Head of Employability at the University decided to work together to find ways of improving students' skills development (particularly employability skills) within the degree and increasing their awareness of these by evaluating the current skills element, incorporating new skills into the course curricula as appropriate and making all skills more evident in the curriculum and course documentation.

The main aim of the Employability Office is to increase the employability of the students, to equip them with career management skills and to encourage and support academic staff in embedding employability and career development learning in the curriculum. Since the research was conducted and since the Employability Office was established, a number of external drivers and quality assurance mechanisms, such as the QAA Code of Practice and the introduction of Progress Files in HE have come on stream and are additional to the ones that motivated this research. These drivers have provided direction for the work of the Employability Office and also reflect, in many ways, the findings of the research outlined in this paper.

In order to identify gaps in the provision and areas for improvement on the BA (Hons) Professional Language Studies, an audit of employability skills provision in the existing curriculum was carried out. Personal development planning (PDP) within the Progress Files agenda provides an excellent framework for embedding the missing aspects into the curriculum.

In conclusion, the presentation gave an example of the lack of student awareness of the importance and extent of their own skills development and demonstrated ways in which PDP for Progress Files has been used on one course to bridge the gap between the students' perceptions of their skills development and the skills requirements of 21st century employers. It is hoped that the experience gained from this case study may be transferable to other contexts and thus contribute towards the enhancement of the quality of students' higher education experience and their preparation for life beyond university.

Indeed, skills needed to become competent in preparation for the business world must be established in the school. With this, it is not just the students who should be continuously trained but also the instructors; and also the development and evaluation of learning and teaching resources and strategies for the College must be a continuing undertaking, to enhance the graduates skills of undergraduates.

The reviewed study is parallel to the present study since both studies focused on the employability and productivity of the graduates. 
Cranmer (2007) reported on the study for the Higher Education Funding Council for England on the impact of employability skills teaching and learning on graduates labor market prospects. The findings of the study cast doubt on the assumption that these skills can be effectively developed within the classrooms. Detailed information gathered at the university department level was drawn to assess how academics perceived and engaged in the teaching and learning of employability, the limitations inherent within the agenda will consistently produce mixed outcomes. Furthermore, it is argued that resources would be better utilized to increase employment; based training and experience, and or employer involvement in courses, which were found to possibly affect immediate graduates in the transitional stage into employment.

The study is related to the present study with respect to skills development in the school which is correlated to the employment status of the graduates.

According to the research report of Dave Hodges and Noel Burchell(2003) on a research report on Business Graduate Competencies: Employer's Views on Importance and Performance 'most employers recognize the importance of graduates' personal characteristics, there is a little agreement on the balance expected between these and there discipline specific technical knowledge (Harvey, Burrows and Green, 1992). However, a review a recent literature examining generic competencies required of graduates, points to increasing emphasis on personal attributes, rather than technical skills (Liston, 1998; Meade and Andrew, 1995; Sweeney and Twomey, 1997; Stasz, 1997; Weisz, 1999). Various authors have proposed a number of competencies required or expected of graduates. For example, Maes, Weldy and Icenogle (1997), Consider oral communication, problem solving and self-motivation to be the three most important competencies required of graduates. Stasz (1997) likewise sees problem-solving, teamwork, communication skills, and personal qualities, as the most important competencies, but suggest that the workplace context determines their relative importance. Joseph and Joseph (1997), in a survey of 208 New Zealand graduate employers, found the top ranked competencies in descending order were: willingness to learn; having a positive attitude; being motivated; having good communication skills; and possessing the ability to work independently. Hence, the literature suggest that the employers of graduates now place major emphasis on generic, behavioral competencies, both in the requirement of graduates for employment, as well as their performance on the job (Raymond, McNabb and Matthaei, 1993; Weisz,1999).

The above cited study is related to the current study which mainly focused on the employability of graduates which is also the main focus of the researcher.

A research study by Pacek (2010) on the Fundamental Differences Between Leaders in Public and Private Organizations which states that employees in the public and the private sectors perform virtually identical tasks and observation of Cook, 1998 which state what makes public administration and public management, public and thus distinctive, the politics of the most fundamental sort are the heart of the enterprise. That public organization is fundamentally different from private organizations as a consequence of the functions they provide to society.

The cited research study emphasized that the school must promote the required skills was also discussed in the research study cited above.

\section{Local Studies:-}

According to the study of Laguador and Ramos, (2014) "curriculum of a certain program must be periodically assessed to ensure its relevance to the needs of the industry to prevent the mismatch between the graduate competencies and those required by employers (Teijeiro et al, 2013). Curriculum development and instructional management serve as an effective tools for meeting the present and future needs of the local and national communities (Valdez, 2012). Lyceum of the Philippines University (LPU) - Batangas as an Autonomous University seeks to enhance the curricular offering of each program through engaging in different meetings with the faculty members, students, alumni as well as the industry-partners to solicit their opinions and ideas that will provide significant contribution to the development of the curricula.

Involvement of the industry-partners in revising the curriculum is very much needed to provide their viewpoints and preferences which are being considered noteworthy confirmation of the efforts of the university in developing relevant knowledge, values and skills to the graduates anchored in the Bloom's Taxonomy of Domains of learning domains. The three domains of educational activities of learning (Bloom, 1956) identified include the cognitive domain which involves mental skills or knowledge, affective refers to growth in feelings or emotional areas like 
attitude or self and psychomotor for manual or physical skills. The school system prepares students for future occupations, develop their skills and provide them with the required knowledge, values and attitudes for the profession (Valdez, 2012).

This study is related to the current study since curriculum development is an important factor to produce competitive graduates that meet the requirements of the school.

Dotong (2014), in his study of School-Related Factors in the Development of Graduates' Competencies Towards Employability states that students can be best acquired from the effective implementation of curriculum through various teaching pedagogies with state-of-the-art facilities, very satisfactory student services , linkages from the partner industries, integration of values and strong participation in research and community extension. The role of academic institutions is to hone the competencies of the student in order for them to achieve the personal and professional growth continuing education after college and let them be glaring symbols and icons of integrity, leadership and nationalism with enormous faith and service for God and country.

The above cited study is almost similar to the present study since it cited the factors such as facilities and linkages with industry partners are big contributing factors to the quality of graduates as illustrated in the conceptual framework presented by the researcher.

According to the study of Camangan (2013), that the employability of the graduates of ALS Livelihood Program is associated with their age and monthly family income while sex and civil status are not significant on their employability.

The study recommended that graduates of ALS Livelihood Program should be given opportunities and assistance in finding a job to ensure the success of the program. Advocacy on the Alternative Learning System should be done by concerned authorities to motivate more clienteles to enroll in the program. The proposed action plan is recommended for implementation. Follow up study on the employability ad productivity of ALS may be conducted.

The study of Camangan is related to the present study since both studies focused on the employability and productivity of graduates. However, they differ in the use of respondents, the reviewed study used the graduates from ALS Livelihood Program while the present study used the graduates from Bachelor of Elementary Education.

Similarly study was conducted by Dimalibot, et al. (2013) on the employment Status of the Tourism Graduates of Batch 2013 in Lyceum of the Philippines University-Batangas. " a growing number of employees and newly graduates must be a fully equipped with knowledge and skills to be competitive in their perspective field. At this point the educational attainment of the individual is given great emphasis. Investment on tertiary education serves as the foundation that prepares the students for their future careers can get a systematic feedback from former students. The researchers focused their study on the Employment Opportunities Among Tourism Graduates of Lyceum of the Philippines University Batangas Batch 2013. Moreover, it described the data and employment status of the graduates, assessed the work-related values to employment, determined the school- related factors affecting graduates employability and proposed an action program to enhance the curriculum and services offered by Lyceum of the Philippines University Batangas towards greater employability rate of graduates. The researcher used the descriptive method or design. The researcher found out that, majority of the graduates are presently employed, all the identified work related values particularly professional integrity was possessed by the respondents, school related factors is very essential for the employability a it has a greater influence on their employment, and proposed curriculum enhancement and program may be sustained for improvement to produce greater employability rate of the graduates.

A study on the employability of graduates was also conducted on above cited study which is very similar to the present study being conducted.

On the study conducted by Musa (2012), it was found out that the ALS A\&E passers mostly have found their jobs for their source of living. Employability o the ALS A\&E passers is associated with their age and monthly family income while sex and civil status are not significant on their employability. 
It was recommended that Passers of ALS Accreditation and Equivalency Program should be given opportunities and assistance in finding a job to ensure the success of the program. Advocacy on the Alternative Learning System should be done by concerned authorities to motivate more clienteles to enroll in the program.

The reviewed study is parallel to the present study since both studies focused on the employability of the graduates. However, they differ on the use of program. The reviewed study used the Alternative Learning System while the present study used the Bachelor of Elementary Education.Likewise, it is parallel to the present study since they all measured the relevance and influence of the school related factors on the employability of the graduates.

All these reviewed literature serve as the researcher's bases in pursuing the conduct of this study. The literature and studies mentioned support the present study on the employability and productivity of Bachelor of Elementary Education graduates, as most of the works cited emphasized the importance of the school, skills developed and the employability of the graduates.

\section{Methodology:-}

\section{and Sources Of Data:-}

This chapter discusses the research design, respondents of the study, instrumentation and validation of instrument, procedure of the study and statistical treatment of data gathered.

\section{Research Design}

The study used the descriptive method of research specifically, the survey design. A questionnaire-checklist was utilized as a tool for gathering data and information for the study.

According to Calmorin (2010) the descriptive evaluative method is designed to gather information about the evaluation of present/existing conditions. It is helpful to express the cause of the phenomena. It involves collection of data in order to test the hypothesis or answer questions concerning the current status of the study. Since the nature of the study involves the gathering and interpreting of detailed information which was used as a basis for the assessment of employability and productivity of Bachelor of Elementary Education graduates, thus, this method is deemed necessary.

Furthermore, descriptive method plays the important role into the study. It helps a lot to determine themale and female respondents, year graduated and who among the respondents are LET passers and LET non-passers. This study used the descriptive method of research since it is a fact finding with adequate interpretation of findings.

\section{Respondents of the Study:-}

The respondents of the study were the total number of students of Bachelor of Elementary Education who graduated from School Years 2012-2013, 2013-2014 and 2014-2015. The respondents were described in terms of age, year graduated and eligibility.

Table 1:-Respondents of the Study

\begin{tabular}{|c|c|}
\hline Year Graduated & Number of Respondents \\
\hline $2012-2013$ & 24 \\
\hline $2013-2014$ & 26 \\
\hline $2014-2015$ & 42 \\
\hline Total & $\mathbf{9 2}$ \\
\hline
\end{tabular}

Table 1 presents the frequency distribution of the respondents.

\section{Instrumentation:-}

The instrument used in the study was the researcher- formulated survey questionnaire-checklist. This served as the main instrument in gathering sufficient data needed for the study, the questionnaire-checklist has two parts. Part I is the profile of respondents such as sex, year graduated and eligibility.

Part II deals with the status of employability of the respondents in terms of nature of employability, nature of work and nature of appointment. Part III deals with the level of productivity of the respondents in terms of professional 
activities and community involvement. Five items were included in each aspect with the total of ten items. The respondents were asked to rate each item following a five-point Likert scale as shown below:

$\begin{array}{rrr}\text { Verbal Interpretation } & \text { Range } & \text { Scale } \\ \text { Always } & 4.50-5.00 & 5 \\ \text { Often } & 3.50-4.49 & 4 \\ \text { Sometimes } & 2.50-3.49 & 3 \\ \text { Seldom } & 1.50-2.49 & 2 \\ \text { Never } & 1.00-1.49 & 1\end{array}$

Validation of the Instrument:-

The instrument was content-validated by the persons knowledgeable in the field of research and research specialist were consulted for the purpose of acquiring their valuable suggestions and comments for more comprehensible contents of the instruments. A pre-trial of questionnaire was conducted to find out if the respondents can easily understand the questions.

Their comments and suggestions were taken into consideration, thus the items were clear, concise and brief for the reason that respondents can easily understand each question.

\section{Procedure of the Study:-}

The researchers were tasked to complete a study on the Employability and Productivity of Bachelor of Elementary Education Graduates in Tomas Claudio Colleges. The researchers together with the Academic Coordinator of the College of Education and Liberal Arts sought assistance from the Research Director for the approval of a one month period research study. A Memorandum of Agreement between the researcher and the administration was duly signed and executed. The next step was to collect the official list of graduates from the Registrar's Office and gathering of graduating program from the Office of the President.

The questionnaire was administered to the respondents indifferent and combined methods. Questionnaire-checklists were hand delivered by the researchers to the houses and place of work of the graduates. The other respondents were contacted through the use of social networking sites, like Facebook, Twitter, Viber, Skype, Google Mail and Yahoo mail wherein the researchers patiently waited to their response and continuous follow-up was the best strategy to collect the answered questionnaire. The researcher attached the questionnaire and sent it thru their email address or Facebook accounts, Twitter accounts and Viber accounts to those graduates working abroad. Some of them responded promptly, while some were delayed in returning their answered questionnaire. In some instances graduate that cannot be meet personally and do not have Email, Facebook accounts, Twitter accounts and Viber accounts where contacted through their mobile phones. The respondents undergo telephone interview in the span of five minutes. These was due to the reason that they don't have an email address, no account in social media sites and their workplace is too far that is why they preferred to answer the questionnaire via telephone/mobile phone interview. Each question was read twice by the researcher without influencing their answer to achieve high reliable and quality respondent from the respondents. Online communications were utilized effectively considering that graduates are scattered from different parts of the province, in Metro Manila and in abroad. It was chosen by the researchers as main method of obtaining data since it is the cheapest means of communication with the fastest response from the graduates with high reliability result.

The responses were tallied and tabulated the data gathered were computed, analyzed and interpreted. Summary of findings were formulated, conclusion were drawn and recommendations were offered.

\section{Statistical Treatment:-}

For the analysis and interpretation of data, the following statistical tools were applied:

1. To determine the profile of therespondents in terms of the selected variables, frequency and percentage were used.

2. To determine the status of employability of the respondents in terms of professional activities and community involvement, frequency and percentage werealso used.

3. To determine the significant associationbetween the employability of the respondents in terms of the selected variables and their profile, Chi-square of association was used. 
4. To determine the level of productivity of the respondents with respect to professional activity and community involvement, weighted mean was utilized.

5. To determine the significant difference between the level of productivity of the respondents in terms of the selected variables and their profile, One Way Analysis of Variance (ANOVA) was used.

Presentation, Analysis And Interpretation Of Data:-

This chapter presents the presentation analysis and interpretation of data based on the sub problems.

Profile of the Respondents in Terms of Sex, Year Graduated and Eligibility:-

Table 2:-Profile of the Respondents in Terms of the Selected Variables.

\begin{tabular}{|l|c|c|}
\hline & Frequency & Percentage \\
\hline Sex & & \\
\hline Male & 27 & 29.3 \\
\hline Female & 65 & 70.7 \\
\hline Year Graduated & & \\
\hline S.Y. 2012-2013 & 24 & 26.1 \\
\hline S.Y. 2013-2014 & 26 & 28.3 \\
\hline S.Y. 2014-2015 & 42 & 45.7 \\
\hline Eligibility & & \\
\hline LET Passer & 29 & 31.52 \\
\hline LET Non-passer & 63 & 68.48 \\
\hline \multicolumn{1}{|c|}{ Total } & 92 & \\
\hline
\end{tabular}

Table 2 presents the profile of the respondents in terms of the selected variables.

As shown in the table, out of 92 respondents, 70.7 percent are females and 29.3 percent are males. With regard to their year graduated, most of the respondents graduated during the School Years 2014-2015 with 45.7 percent, 28.3 percent and 26.1 percent are graduates from the School Years 2013-2014 and 2012-2013. In terms of their eligibility, 31.52 percent were LET Passers and 68.48percent were LET Non-Passers.

The Status of Employability of the Respondents with Respect to Nature of Employment, Nature of Work and Nature of Appointment:-

Table 3:-Frequency and Percentage Distribution of the Graduates of Bachelor of Elementary Education in Terms of Nature of Employment

\begin{tabular}{|l|r|r|}
\hline Nature of Employment & f & \% \\
\hline Employed & 72 & 78.3 \\
\hline Self-Employed & 15 & 16.3 \\
\hline Unemployed & 5 & 5.4 \\
\hline & $\mathbf{3 9 2}$ & $\mathbf{1 0 0}$ \\
\hline
\end{tabular}

Table 3 shows the frequency and percentage distribution of the graduates of Bachelor of Elementary Education in terms of nature of employment.

As shown in the table, out of 92 respondents. 78.3 percent are employed, 16.3 are self-employed and 5.4 percent are unemployed. It could be gleaned from the results that majority of the respondents have engaged to finding a job as a source of their living. This means that their knowledge gained from the school program offered by the school contributed to their opportunities in finding a job.

This implies that the graduates of Bachelor of Elementary Education have found their place in the world of work. This is in line with the statements of Ballon (2007) graduates are faced with the challenge of acquiring employment right after graduation. It is paramount that they should have gained the best knowledge and skills in their field of specialization before plunging into any workplace of their choice.

Table 4:-Frequency and Percentage Distribution of the Graduates of Bachelor of Elementary Education in Terms of Nature of Work.

\begin{tabular}{|l|c|c|}
\hline Nature of Work & f & \% \\
\hline Teaching & 53 & 57.6 \\
\hline
\end{tabular}




\begin{tabular}{|l|l|l|}
\hline Business & 22 & 23.9 \\
\hline Others Composite Mean & 17 & 18.5 \\
\hline & $\mathbf{9 2}$ & $\mathbf{1 0 0}$ \\
\hline
\end{tabular}

Table 4 shows the frequency and percentage distribution of the graduates of Bachelor of Elementary Education in terms of nature of work.

It could be gleaned from the table that majority of the graduates are in the field of teaching with 57.6 percent, 23.9 have put up their business and 18.5 percent are engaged in other works.

The findings reveal that the graduates of Bachelor of Elementary Education have different nature of work but majority of them are engaged in the field of teaching. This implies that the learning acquired by the respondents have provided them the necessary skills required in the world of the teaching-learning process. Likewise, it also provided them the occupation where they could practice their chosen career.

This supports the statements of De Guzman and De Jesus (2008) that graduates are exhorted to develop personal skills, qualities, and experiences that enable them to compete in the labor market.

Table 5:-Frequency and Percentage Distribution of the Graduates of Bachelor of Elementary Education in Terms Nature of Appointment.

\begin{tabular}{|l|c|c|}
\hline Nature of Appointment & f & \% \\
\hline Regular/Permanent & 15 & 16.3 \\
\hline Casual & 5 & 5.4 \\
\hline Contractual & 46 & 50.0 \\
\hline Others Composite Mean & 26 & 28.3 \\
\hline
\end{tabular}

Table 5 shows frequency and percentage distribution of the graduates of Bachelor of Elementary Education in terms of nature of appointment.

As shown in the table, out of 92 respondents 16.3 percent have regular and permanent position in the job where they are employed, 5.4 percent are casual, 50 percent have contractual appointments and 50 percent have other nature of appointment which are not employed, provisional/temporary and self-employed.

The findings indicate that the respondents are hired and appointed according to their learned skills and become lifelong learners. They engaged their understanding in the world of labor market.

This negates with the statements of Yahya Buntat, et al. (2012), the employability skills that are integrated into the agricultural vocational education programs. The five mean elements of employability skills which were always integrated by the teaching staff of agricultural vocational training institutions during the teaching process were: "cooperating with others", "working in a team", "possessing honesty", "following instructions given", and "interacting with others".

\section{Significant Association on the Status of Employability of the Respondents in terms of the Selected Variables} and their Profile:-

Table 6:-Computed Chi-Square on the Employability of the Respondents in terms of the Selected Variables and their Profile

\begin{tabular}{|c|c|c|c|c|}
\hline & $\chi_{\text {comp }}^{2}$ & $\chi_{\text {tab }}^{2}$ & Decision & Verbal Interpretation \\
\hline \multicolumn{5}{|l|}{ Sex } \\
\hline Nature of Employment & 10.615 & .005 & Reject Ho & Significant \\
\hline Nature of Work & 11.933 & .003 & Reject Ho & Significant \\
\hline Nature of Appointment & 79.003 & ,000 & Reject Ho & Significant \\
\hline \multicolumn{5}{|l|}{ Year Graduated } \\
\hline Nature of Employment & 41.872 & .000 & Reject Ho & Significant \\
\hline Nature of Work & 34.931 & .000 & Reject Ho & Significant \\
\hline Nature of Appointment & 107.143 & .000 & Reject Ho & Significant \\
\hline Eligibility & & & & \\
\hline
\end{tabular}




\begin{tabular}{|l|l|l|l|l|}
\hline Nature of Employment & 23.637 & .000 & Reject Ho & Significant \\
\hline Nature of Work & 33.928 & .000 & Reject Ho & Significant \\
\hline Nature of Appointment & 46.000 & .000 & Reject Ho & Significant \\
\hline
\end{tabular}

Table 6 presents the computed chi-square values on the employability of the respondents in terms of the selected variables and their profile.

As shown in the table, with respect to all the aspects of employability of the respondents, all the computed chisquare values are greater than the tabular chi-square values at 0.05 level of significance.

The null hypothesis stating that there is no significant association on the status of employability of the respondents with respect to nature of employment, nature of work and nature of appointment is rejectedted. This means that the respondents' employability is associated withtheir sex, year graduated and eligibility.

The findings imply that the respondents' sex, year graduated and eligibility are contributory for being employed of an individual. This is similar to the findings of Musa (2012) that the selected variables are significant on the employability of the graduates.

The Level of Productivity of the Respondents with Respect to Professional Activity and Community Involvement:-

As indicated from the table, the level of productivity of the graduates with respect to professional activity is perceived to be Always as shown by the composite mean of 4.56. The graduates of Bachelor of Elementary Education, after their employment always attended several training for them to have a professional advancement with regard to their field of work as indicated by the highest weighted mean of 4.74 . They also kept themselves busy in attending seminars related to the

Table 7:-Computed Weighted Mean on the Level of Productivity of the Respondents with Respect to Professional Activities

\begin{tabular}{|c|c|c|c|}
\hline $\begin{array}{l}\text { Professional Activities } \\
\text { After my employment, I.. }\end{array}$ & $\mathbf{w x}$ & VI & $\mathbf{R}$ \\
\hline 1. engaged myself in some professional undertakings. & 4.22 & $\mathrm{O}$ & 5 \\
\hline $\begin{array}{l}\text { 2. kept myself busy in attending seminars related to my field of } \\
\text { specialization. }\end{array}$ & 4.66 & $\mathrm{~A}$ & 2 \\
\hline 3. felt motivated to teach along my area of specialization. & 4.55 & A & 4 \\
\hline 4. Attended several training tohave my professional advancement. & 4.74 & A & 1 \\
\hline 5. was encouraged to pursue graduate studies. & 4.63 & A & 3 \\
\hline Composite Mean & 4.56 & $\mathbf{A}$ & \\
\hline
\end{tabular}

Table 7 shows the computed weighted mean on the level of productivity of the respondents with respect to professional activity.

Their field of specialization as justified by the weighted mean of 4.66. They are also often engaged themselves in their professional activities as reflected by the weighted mean of 4.22 .

The data reveal that the graduates are always engaging themselves to become more advanced and productive in their professional activity. This means that they are engaging themselves to attained more advance and efficient in the teaching learning-process. This is aligned with the study of Dotong (2014) that students can be best acquired from the effective implementation of curriculum through various teaching pedagogies with state-of-the-art facilities, very satisfactory student services, linkages from the partner industries, integration of values and strong participation in research and community extension.

Table 8:-Computed Weighted Mean on the Level of Productivity of the Respondents with Respect to Community Involvement.

\begin{tabular}{|l|c|c|c|}
\hline $\begin{array}{l}\text { Community Involvement } \\
\text { After my employment, I... }\end{array}$ & wx & VI & R \\
\hline $1 . \quad$ became very active in some community activities. & 4.72 & A & 1 \\
\hline $2 . \quad$ served as officer in some civic organizations. & 4.55 & A & 5 \\
\hline
\end{tabular}




\begin{tabular}{|l|l|c|c|}
\hline $3 . \quad$ engaged myself in extension activities of our barangay. & 4.65 & $\mathrm{~A}$ & 3 \\
\hline $4 . \quad$ joined religious groups to develop my spiritual well-being. & 4.70 & $\mathrm{~A}$ & 2 \\
\hline $5 . \quad$ became active in attending productive activities. & 4.59 & $\mathrm{~A}$ & 4 \\
\hline Composite Mean & $\mathbf{4 . 6 4}$ & $\mathrm{A}$ & \\
\hline
\end{tabular}

Table 8 shows the computed weighted mean on level of productivity of the respondents with respect to community involvement.

As shown in the table, the composite mean of the respondents 4.64 verbally interpreted as Always. They became active and engaged themselves in the community activities.

This is a clear manifestation of their level of increased level of productivity. This is in consonance with the research report of Dave Hodges and Noel Burchell (2003) that most employers recognize the importance of graduates' personal characteristics, there is a little agreement on the balance expected between these and there discipline specific technical knowledge.

Table 9:-shows that summary of the perceptions of the respondents on the level of productivity.

\begin{tabular}{|l|c|c|c|}
\hline & WX & VI & R \\
\hline Professional Activities & 4.56 & $\mathrm{~A}$ & 2 \\
\hline Community Involvement & 4.64 & $\mathrm{~A}$ & 1 \\
\hline \multicolumn{1}{|c|}{ Grand Mean } & $\mathbf{4 . 6 0}$ & $\mathrm{A}$ & \\
\hline
\end{tabular}

Table 9. Summary of the Perceptions of the Respondents on the Level of Productivity

The result indicates that the perception of the respondents on the level of productivity obtained a grand mean of 4.60 indicated as Always. Community Involvement ranked first with a weighted mean of 4.64, followed by professional activity with a weighted mean of 4.56 where both interpreted as Always respectively.

The findings imply that the respondents are professionally active and likewise they involved themselves in different community activities. This may be due to the fact that teachers need to participate more actively in their respective community thereby developing their ability to communicate well with the stakeholders which is indeed significant in developing the harmonious relationship. This conforms to the study of Dimalibot et al. (2013) that a growing number of employees and newly graduates must be a fully equipped with knowledge and skills to be competitive in their perspective field.

The Significant Difference Between the Level of Productivity of the Respondents with Respect to Professional Activities and Community Involvement in Terms of their Profile:-

Table 10:-Computed f-value on the Level of Productivity of the Respondents with Respect to Professional Activities and Community Involvement in terms of their Profile

\begin{tabular}{|c|c|c|c|c|}
\hline & F-value & p-value & Decision & Verbal Interpretation \\
\hline \multicolumn{5}{|r|}{ 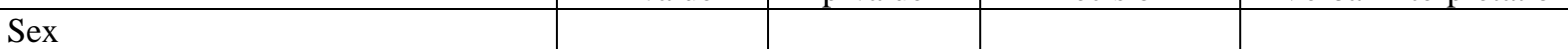 } \\
\hline Professional Activity & 8.217 & .005 & Reject Ho & Significant \\
\hline Community Involvement & .067 & .796 & Accept Ho & Not Significant \\
\hline \multicolumn{5}{|l|}{ Year Graduated } \\
\hline Professional Activities & 3.577 & .032 & Reject Ho & Significant \\
\hline Community Involvement & .849 & .431 & Accept Ho & Not Significant \\
\hline \multicolumn{5}{|l|}{ Eligibility } \\
\hline Professional Activity & 14.072 & .000 & Reject Ho & Significant \\
\hline Community Involvement & .069 & .794 & Accept Ho & Not Significant \\
\hline
\end{tabular}

Table 10 presents the f-value on the level of productivity of the respondents with respect to Professional Activity and Community Involvement in terms of their profile.

The table shows that the level of productivity of the respondents with respect to professional activities is rejected. Thus, it reveals that there is a significant difference as perceived by the respondents with respect to sex, year graduated and eligibility. However, it shows that the level of productivity of respondents with respect to community involvement is accepted which reveals that there is no significant difference as perceived by the respondents. 
The findings imply that sex, year graduated and eligibility are contributory on the perceptions of the respondents with respect to professional activity. However, when it comes to community involvement, the cited variables are not contributory. This maybe due to the fact that the respondents regardless of their sex, year graduated and eligibility, they engaged themselves in different community activities which are indeed significant in developing communication and cooperation among the members of the community.

This is parallel to the study conducted by Leggott and Stapleford (2016), that to contribute towards the enhancement of the quality of students' higher education experience and their preparation for life beyond university is really indeed an important factor.

Action Plan to Enhance the Status of Employability and Productivity of the Bachelor of Elementary Education Graduates of Tomas Claudio Colleges:-

Based on the findings, the researchers crafted a proposed action plan for the enhancement of the status of employability and productivity of the graduates of Bachelor of Elementary Education.

\section{Conclusions And Recommendations:-}

Summary Of Findings:-

This chapter presents the summary of findings, conclusions drawn and recommendation offered.

\section{Summary of Findings:-}

Based on the analysis and interpretation of data, the findings are hereby summarized:

Profile of the Respondents in Terms of Sex, Year Graduated and Eligibility:-

Majority of the respondents are females and graduates from School Year 2014-2015. There is a less percen

LET Passers from the respondents.

The Status of Employability of the Respondents with Respect to Nature of Employment, Nature of Work and Nature of Appointment:-

Majority of the respondents are employed and in the field of teaching. Most of them were hired as contractual.

Significant Association on the Status of Employability of the Respondents in terms of the Selected Variables and their Profile:-

Sex, year graduated and eligibility are not significantly associated with the employability of the respondents.

The Level of Productivity of the Respondents with Respect to Professional Activities and Community Involvement:-

Professional Activity and Community Involvement are interpreted as Always.

The Significant Difference Between the Level of Productivity of the Respondents with Respect to Professional Activities and Community Involvement in Terms of their Profile:-

Sex, year graduated and eligibility are significant to the respondents on the level of productivity of the respondents with respect to the aspect professional activities.

Sex, year graduated and eligibility are not significant the respondents on the level of productivity of the respondents with respect to the aspect community involvement.

\section{Conclusions:-}

The study concluded that:-

1. There is no significant association on the status of employability of the respondents with respect to nature of employment, nature of work and nature of appointment in terms of sex, year graduated and eligibility.

2. There is no significant difference between the level of productivity of the respondents with respect to community involvement in terms of sex, year graduated and eligibility and there is a significant difference between the level of productivity of the respondents with respect to professional activities in terms of sex, year graduated and eligibility. 


\section{Recommendations:-}

In the light of the findings, the following recommendations are hereby offered:-

1. Graduates of Bachelor of Elementary Education should continuously involve themselves in different community activities.

2. They should likewise attend seminars and trainings to strengthen their professional involvement.

3. The proposed action plan is recommended for implementation.

4. Parallel studies may be conducted considering other variables.

\section{Journals/Magazines:-}

Akinwumi, FS., "Mode of Supervision and Teacher Productivity", Nigerian Journal of Clinical and Counseling Psychology Vol.8(2) 2002: 219-228, 2002.

Ballon, Alexie E., "Predictors of Employability of the Graduates of Technological Institute of the Philippines Quezon City", TIP-QC Research Journal, Vol. 4, No 1., 2007.

De Guzman, Allan B. and De Castro Belinda V., "Employment and Employability Profile of a Select Group of Filipino College Graduates”, KEDI Journal of Educational Policy; 2008, Vol. 5 Issue 1, p63, 2008.

\section{Unpublished Materials:-}

Camangan, Teresita R., "Employability of Graduates of Alternative Learning System Livelihood Program in Tanay, Rizal”, Master's Thesis. Tomas Claudio Memorial College, Morong, Rizal, 2013.

Musa, Roberto 1., "Employability of Alternative Learning System Accreditation and Equivalency Passers in Tanay, Rizal”, Unpublished Thesis, Tomas Claudio Memorial College, Morong, Rizal, 2012.

\section{Internet Sources:-}

1. Cranmer, Sue, "Enhancing Graduate Employability: Best Intensions and Mixed Outcomes". Retrieved from http://www.tandfonline.com/doi/abs/ on January 12, 2016.

2. Dotong, Condrado I., "School Related Factors in the Development of Graduates' Competencies towards Employability". Retrieved from http://research.lpubatangas.edu.ph/wp-content/uploads/2014/10/JEL- School$\%$ E2\%80\%93-related-Factors-in-the-Development-of- Graduates\%E2\%80\%99-Competencies-towardsEmployability.pdf on January 10, 2016.

3. Dickinson, James C., "The Employability of Disabled Elementary Teachers". Retrieved from http://onlinelibrary.wiley.com/doi/10.1002/j.21646171.1969.tb00152.x/abstract;jsessionid=DB6067D05A296EA9567F3644BAA651A7.f02t04 on January 17, 2016.

4. Dimalibot, Ginhie A., et al. , "Employment Status of the Tourism Graduates of Batch 2013 in Lyceum of the Philippines University-Batangas", Retrieved from http://research.lpubatangas.edu.ph/wpcontent/uploads/2014/08/JTHR-Employment-Status.pdf on January 17, 2016.

5. Laguador, Kae M. and Ramos, Jr. Leon R., "Induswtry-Partner' Preferences for Graduates: Input on Curriculum Development". Retrieved from http://research.lpubatangas.edu.ph/wpcontent/uploads/2014/06/JEL-Industry-Partners\%E2\%80\%99-Preferences-for-Graduates.pdf on January 9, 2016.

6. Leggott Dawn and Stapleford Jane, "Enhancing Student Awareness of Employability Skills through the Use of Progress Files". Retrieved from https://www.llas.ac.uk/resources/paper/2279 on January 13, 2016.

7. Marsh, Herbert W. and Hattie, John., "The Relation Between Research Productivity and Teaching Effectiveness: Complementary, Antagonistic, or Independent Constructs?". Retrieved from https://muse.jhu.edu/login?auth=0\&type=summary\&url=/journals/journal_of higher_education/v073/73.5mar sh.html on January 13, 2016.

8. Pacek, Lauren, "Fundamental Differences between Leaders in Public and Private Organizations". Retrieved from http://www.academia.edu/3481145/Fundamental_Differences_in_Leadership_in_Public _Private_Organizations on January 11, 2016. 
9. Shulls James V. and Trivitt Julie R., "Teacher Qualifications and Productivity in Secondary Schools". Retrieved from http://www.tandfonline.com/doi/abs/10. 1080/15582159. 2015.998964 on January 12, 2016.

10. Yahya Buntat, et al., "Employability Skills Element's: Difference Perspective Between Teaching Staff and Employers Industrial in Malaysia". Retrieved from http://www.sciencedirect.com/science/article /pii/S1877042813035222 on January 12, 2016.

\section{Methodology:-}

Descriptive Survey Research Method.

\section{Conclusions and Recommendations:-}

\section{Findings:-}

The study aimed to determine the employability and productivity of Bachelor of Elementary Education graduates during the School Year 2012-2013, 2013-2014, and 2014-2015. The respondents of the study were the total population of the graduates during the School Years 2012-2013, 2013-2014 and 2014-2015. The respondents were described in terms of sex, year graduated and eligibility. The employability of the respondents was determined in terms of nature of employment, nature of work and nature of appointment. The level of productivity was determined from their engagement in professional activities and community involvement. Data were obtained through a checklist consisting of three parts. Descriptive survey research design was utilized in the study.

Majority of the respondents are females and graduates from School Year 2014-2015. There is a less percentage of LET Passers from the respondents. Majority of the respondents are employed and in the field of teaching. Most of them were hired as contractual. Sex, year graduated and eligibility are not significantly associated with the employability of the respondents. Professional activities and community involvement are interpreted as Always. Sex, year graduated and eligibility is significant to the respondents on the level of productivity of the respondents with respect to the aspect professional activity. Sex, year graduated and eligibility are not significant the respondents on the level of productivity of the respondents with respect to the aspect community involvement.

The study concluded that there is no significant association on the status of employability of the respondents with respect to nature of employment, nature of work and nature of appointment in terms of sex, year graduated and eligibility. There is no significant difference between the level of productivity of the respondents with respect to community involvement in terms of sex, year graduated and eligibility and there is a significant difference between the level of productivity of the respondents with respect to professional activity in terms of sex, year graduated and eligibility.

The study recommended that graduates of Bachelor of Elementary Education should continuously involve themselves in different community activities. They should likewise attend seminars and trainings to strengthen their professional involvement. The proposed action plan is recommended for implementation and parallel studies may be conducted considering other variables.

\section{Bibliography:-}

1. Books, Calmorin, Laurentina P. et al., Methods of Research and Thesis Writing, Mandaluyong City: National Bookstore, 2010.

2. Nolledo, Jose N., 1987 Philippine Constitution, Mandaluyong City: National Bookstore. 2012.

3. Patterson, Josephine Ph. D., Humanistic Theory. New York: Wiley Publication, 2008.

4. Zulueta, Francisco M., Education Alternatives, Manila, Rex Bookstore, 2004. 